\title{
Fisetin Induces Apoptosis of HSC3 Human Oral Cancer Cells Through Endoplasmic Reticulum Stress and Dysfunction of Mitochondria-mediated Signaling Pathways
}

\author{
YUNG-LUEN SHIH ${ }^{1,2,3^{*}}$, FANG-MING HUNG ${ }^{4 *}$, CHING-HSIAO LEE ${ }^{5}$, MING-YANG YEH ${ }^{6}$, MEI-HUI LEE ${ }^{7}$, \\ HSU-FENG LU ${ }^{8,9}$, YUNG-LIANG CHEN ${ }^{10}$, JIA-YOU LIU ${ }^{9}$ and JING-GUNG CHUNG ${ }^{11}$ \\ ${ }^{1}$ Department of Pathology and Laboratory Medicine, \\ Shin Kong Wu Ho-Su Memorial Hospital, Taipei, Taiwan, R.O.C.; \\ ${ }^{2}$ School of Medical Laboratory Science and Biotechnology, Taipei Medical University, Taipei, Taiwan, R.O.C.; \\ ${ }^{3}$ School of Medicine, College of Medicine, ${ }^{8}$ Department of Restaurant, Hotel and Institutional Management, \\ Fu-Jen Catholic University, New Taipei City, Taiwan, R.O.C.; \\ ${ }^{4}$ Department of Surgical Intensive Care Unit, Far Eastern Memorial Hospital, New Taipei, Taiwan, R.O.C.; \\ ${ }^{5}$ Department of Medical Technology, Jen-Teh Junior College of Medicine, \\ Nursing and Management, Miaoli County, Taiwan, R.O.C.; \\ ${ }^{6}$ Department of Medical Education and Research, Cheng Hsin General Hospital, Taipei, Taiwan, R.O.C.; \\ ${ }^{7}$ Department of Genetic Counseling Center, Changhua Christian Hospital, Changhua, Taiwan, R.O.C.; \\ ${ }^{9}$ Department of Clinical Pathology, Cheng Hsin General Hospital, Taipei, Taiwan, R.O.C.; \\ ${ }^{10}$ Department of Medical Laboratory Science and Biotechnology, Yuanpei University, Hsinchu, Taiwan, R.O.C.; \\ ${ }^{11}$ Department of Biological Science and Technology, China Medical University, Taichung, Taiwan, R.O.C.
}

\begin{abstract}
Background/Aim: Oral cancer has been reported to be one of the major cancer-related diseases in human populations and the treatment of oral cancer is still unsatisfied. Fisetin, is a flavonoid from plants and has several biological activities such as antioxidant, anti-inflammatory and anticancer function, but its cytotoxicity in human oral cancer cells is unknown. In the present study, we investigated fisetin-induced cytotoxic effects on HSC3 human oral cancer cells in vitro. Materials and Methods/Results: We used flow cytometric assay to show fisetin induced apoptotic cell death
\end{abstract}

This article is freely accessible online.

\footnotetext{
*These Authors contributed equally to this study.

Correspondence to: Jing-Gung Chung, Ph. D., Department of Biological Science and Technology, China Medical University. No 91, Hsueh-Shih Road, Taichung 40402, Taiwan, R.O.C. Tel: +886 422053366 ext. 8000, Fax: +886 422053764, e-mail: jgchung@mail.cmu.edu.tw and Jia-You Liu, Department of Clinical Pathology, Cheng-Hsin General Hospital, No.45, Cheng Hsin St., Pai-Tou, Taipei 112, Taiwan, R.O.C. Tel: +886228264400 ext. 5850; Fax: +886 228264517, e-mail: ch1835@chgh.org.tw
}

Key Words: Fisetin, mitochondria, DNA damage, AIF, ENDO G, HSC 3 cells. through increased reactive oxygen species and $\mathrm{Ca}^{2+}$, but reduced the mitochondrial membrane potential and increased caspase-8, -9 and -3 activities in HSC 3 cells. Furthermore, we also used 4' 6-diamidino-2-phenylindole staining to show that fisetin induced chromatin condensation (apoptotic cell death), and Comet assay to show that fisetin induced DNA damage in HSC3 cells. Western blotting was used to examine the levels of apoptotic-associated protein and results indicated that fisetin increased expression of pro-apoptotic proteins such as B-cell lymphoma 2 (BCL2) antagonist/killer $(B A K)$ and BCL2-associated $X(B A X)$ but reduced that of anti-apoptotic protein such as BCL2 and BCL-x, and increased the cleaved forms of caspase-3, -8 and -9 , and cytochrome $c$, apoptosis-inducing factor (AIF) and endonuclease $G$ (ENDO G) in HSC3 cells. Confocal microscopy showed that fisetin increased the release of cytochrome c, AIF and ENDO G from mitochondria into the cytoplasm. Conclusion: Based on these observations, we suggest that fisetin induces apoptotic cell death through endoplasmic reticulum stress- and mitochondria-dependent pathways.

Oral cancer is a subtype of head and neck squamous cell carcinoma. Oral squamous cell carcinoma (OSCC) comprises of a large proportion of head and neck SCC (1). In men, oral cancer constitutes approximately $3 \%$ of all malignant 
neoplasms, but in females about $2 \%$. The incidence in the past decade has increased up to almost five-fold in those younger than 40 years old (2). Oral cancer is the fifth common cancer in males in Taiwan and around 13 individuals per 100,000 die annually from oral cancer based on a report in 2017 from the Department of Health, R.O.C. (Taiwan) (3). Currently, primary surgery, definitive radiation therapy and chemotherapy or combination of chemo- and radiotherapy are options for patients with oral cancer. However, these therapies can have a profound effect on the quality of life of survivors $(4,5)$. Thus, dose-limiting toxicities in patients with cancer restrict the clinical utility of such therapies. Many studies have focused on compounds from natural products for treating patients with oral cancer. Cell cycle progression occurs through multiple cascades regulated by cyclins and cyclin-dependent kinases (CDKs) (6); and the formation of complex of cyclin with CDKs can lead to phosphorylation of substrates involved in cell-cycle progression. Therefore, many anticancer drugs affect cyclins or CDKs, leading to cell-cycle arrest. Apoptosis is a type of programmed cell death with characteristics such as cytoplasmic shrinkage, nuclear chromatin condensation, and DNA fragmentation and apoptotic body in cells after exposure anticancer chemotherapeutic drugs (7-9). Thus, a good strategy for anticancer agent activity is to induce cancer cell apoptosis.

Herbal medicines have been used to treat a variety of human cancer types (10) and some of these herbal medicines and natural plants contain flavonoids $(11,12)$. These flavonoids are recognized to have anticancer and chemopreventive functions via antioxidant activity, inhibition of cell proliferation and angiogenesis, and induction of cellcycle arrest and apoptosis (13). Fisetin (3,7,3', 4'tetrahydroxyflavone), a naturally-occurring flavonoid, is widely distributed among edible vegetables and fruits such as apple, cucumber, grapes, kiwis, onion, persimmon and strawberry, the highest level of fisetin $(160 \mu \mathrm{g} / \mathrm{g}$ wet food) being found in strawberries (14). Numerous studies have shown that fisetin has pharmacological activities such as antioxidant (15), anti-inflammatory (16), anti-invasive (17, $18)$, anti-angiogenesis $(19,20)$, anti-proliferation $(21,22)$ and anticancer effects in several cancer types, such as prostate cancer $(22,23)$, lung adenocarcinoma $(20,24)$, pancreatic cancer (25), colon cancer (26), cervical cancer (27), melanoma (28) and acute monocytic leukemia cells (29). Recently, it was reported that combination treatment of fisetin and sorafenib effectively inhibited B-Raf proto-oncogene serine/threonine-protein kinase $(B R A F)$-mutated melanoma cell growth, induced apoptosis, and down-regulated mitogenactivated protein kinase (MAPK) and phosphoinositide 3kinase (PI3K) signaling pathways in vitro and in vivo.

Although numerous studies have shown that fisetin induces cell apoptosis in many human cancer cell lines, there is no information available on the effects of fisetin on human oral cancer cell lines. The present study was designed to analyze the anticancer potential of fisetin against human oral cancer HSC3 cells in vitro.

\section{Materials and Methods}

Chemicals and reagents. Fisetin of 99\% purity, 4' 6-diamidino-2phenylindole (DAPI), dimethyl sulfoxide (DMSO), propidium iodide (PI) and trypsin-EDTA were obtained from Sigma Chemical Co. (St. Louis, MO, USA). Minimum essential medium (MEM), fetal bovine serum (FBS), L-glutamine and penicillin-streptomycin were purchased from GIBCO ${ }^{\circledR} /$ Invitrogen Life Technologies (Carlsbad, CA, USA). Fisetin was dissolved in DMSO.

Cell culture. HSC3 human oral cancer cell line was purchased from the Food Industry Research and Development Institute (Hsinchu, Taiwan, ROC). These cells were placed in MEM supplemented with $10 \%$ FBS, 100 units $/ \mathrm{ml}$ penicillin, $100 \mu \mathrm{g} / \mathrm{ml}$ streptomycin, and 2 $\mathrm{mM}$ glutamine and were growth at $37^{\circ} \mathrm{C}$ in a humidified atmosphere consisting of $5 \% \mathrm{CO}_{2}(30)$.

Cell viability assays. HSC 3 cells $\left(5 \times 10^{4}\right.$ cells $\left./ \mathrm{ml}\right)$ were seeded and cultured in 12-well plates with MEM for $24 \mathrm{~h}$ and then fisetin was added to each well at final concentrations of $0,20,40,60,80$ and 100 $\mu \mathrm{M}$. After incubation for 24 and 48 hours, cells were harvested, counted and stained with PI $(5 \mu \mathrm{g} / \mathrm{ml})$ followed by immediately analysis by flow cytometry (FACSCalibur; BD Biosciences, San Jose, CA, USA) for total percentage of viable cells as previously described (30).

DAPI staining. Cells $\left(5 \times 10^{4}\right.$ cells $\left./ \mathrm{ml}\right)$ were plated in a 12 -well plate and treated with fisetin $(40 \mu \mathrm{M})$ for $0,12,24$ and 48 hours and then fixed in $3 \%$ methanol in PBS at room temperature for $20 \mathrm{~min}$. Cells were stained with DAPI solution $(2 \mu \mathrm{g} / \mathrm{ml})$ and photographed under fluorescence microscopy as described previously (31). Nuclear condensation of cells relative to total cells was evaluated, with a minimum of 150 cells/field and at least three fields in each well being counted.

DNA damage measurement. HSC 3 cells $\left(5 \times 10^{4}\right.$ cells $\left./ \mathrm{ml}\right)$ were cultured in 12-well plates for 24 hours and were then treated with fisetin $(40 \mu \mathrm{M})$ for $0,12,24$ and 48 hours. Cells were then collected for comet assay as described previously (32).

Measurement of reactive oxygen species (ROS), intracellular $\mathrm{Ca}^{2+}$ and mitochondrial membrane potential $\left(\Psi_{m}\right)$. The measurement of ROS, $\mathrm{Ca}^{2+}$ and $\Delta \Psi_{\mathrm{m}}$ in HSC3 cells after exposure to fisetin were performed by flow cytometric assay. In brief, HSC 3 cells $\left(5 \times 10^{4}\right.$ cells $/ \mathrm{ml})$ in 12 -well plate were treated with fisetin $(40 \mu \mathrm{M})$ for 0 , 6, 24 and 48 hours. For ROS $\left(\mathrm{H}_{2} \mathrm{O}_{2}\right)$ measurement, cells were isolated and re-suspended with $500 \mu \mathrm{l}$ of 2', 7'-dichlorfluoresceindiacetate (DCFH-DA) (Sigma Chemical Co.) $(10 \mu \mathrm{M})$ and kept in the dark for 30 minutes. For intracellular $\mathrm{Ca}^{2+}$ measurement, cells were isolated and re-suspended with $500 \mu \mathrm{l}$ of fluo-3acetomethoxyester (Fluo-3/AM) (Invitrogen) $(2.5 \mu \mathrm{g} / \mathrm{ml})$ maintained in the dark for $30 \mathrm{~min}$. For $\Delta \Psi_{m}$ measurement, cells were isolated and re-suspended with $500 \mu \mathrm{l}$ of 3,3'-dihexyloxacarbocyanine iodide $\left(\mathrm{DiOC}_{6}\right)($ Sigma Chemical Co. $)(4 \mu \mathrm{mol} / \mathrm{l})$ and maintained in the dark for 30 minutes. After incubation, all samples were analyzed by flow cytometry as described previously (33-35). 

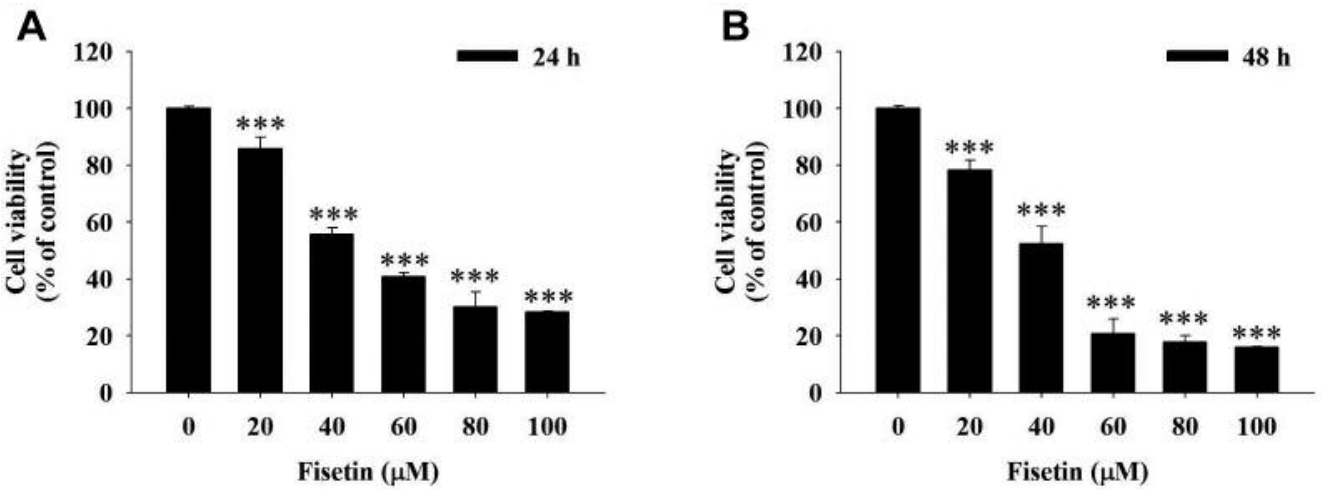

Figure 1. Fisetin reduced HSC3 cell viability. HSC3 cells were treated with 0,20,40,60,80 and $100 \mu \mathrm{M}$ of fisetin for 24 (A) and 48 (B) h and then cells were collected to determine the total percentage of viable cells by flow cytometry as described in the Materials and Methods section. ***Significant differences at $p<0.001$ between fisetin-treated groups and the control as analyzed by Dunnett test.

Measurements of caspase activities. Flow cytometry was used for measuring caspase- $3,-8$ and -9 activities. In brief, HSC3 cells $\left(5 \times 10^{4}\right.$ cells $\left./ \mathrm{ml}\right)$ were plated in a 12 -well plate and treated with 40 $\mu \mathrm{M}$ of fisetin for $0,6,24$ and $48 \mathrm{~h}$ then cells were harvested and re-suspended in $25 \mu \mathrm{l}$ of $10 \mu \mathrm{M}$ substrate solution containing PhiPhiLux- $\mathrm{G}_{1} \mathrm{D}_{1}$ for caspase-3, or CaspaLux $8-\mathrm{L}_{1} \mathrm{D}_{2}$ for caspase- 8 or CaspaLux9- $\mathrm{M}_{1} \mathrm{D}_{2}$ (both from OncoImmunin, Gaithersburg, $\mathrm{MD}$, USA) for caspase- 9 determination before being incubated at $37^{\circ} \mathrm{C}$ for $60 \mathrm{~min}$. After incubation, all samples were washed with PBS and caspase activities were analyzed by flow cytometry as described previously $(31,32,36)$.

Western blotting analysis. HSC3 cells $\left(1.5 \times 10^{6}\right.$ cells/dish) were placed in a $10 \mathrm{~cm}$ dish for 24 hours and then were incubated with $40 \mu \mathrm{M}$ fisetin for $0,12,24$ and 48 hours. Cells were collected and lysed and total protein was determined by Bio-Rad protein assay kit (Bio-Rad Laboratories, Inc., Hercules, CA, USA). Equal amounts of protein extracts were separated by $8-14 \%(\mathrm{v} / \mathrm{v})$ sodium dodecyl sulfate-polyacrylamide gel electrophoresis and transferred onto polyvinylidene difluoride membranes (EMD Millipore, Billerica, MA, USA). After blocking, the membranes were hybridized with primary antibodies against myeloid cell leukemia-1 (MCL1), B-cell lymphoma 2 (BCL2), apoptosis regulator Bcl-X (BCLX), BH3interacting domain death agonist (BID), BCL2-associated agonist of cell death (BAD), BCL2 antagonist/killer (BAK), BCL2-associated $\mathrm{X}$ (BAX), apoptosis-inducing factor (AIF), endonuclease G (ENDO $\mathrm{G}$ ), cytochrome $c$, apoptotic peptidase activating factor 1 (APAF1), caspase-9, X-linked inhibitor of apoptosis (XIAP), caspase-3, caspase-6, poly-(ADP-ribose) polymerase (PARP), Fas cell surface death receptor (FAS), FAS-ligand, caspase-8, activating transcription factor 6-beta (ATF-6 $\beta$ ), calpain 1, caspase-4, glucose-regulated protein 78 (GRP78) and $\beta$-Actin at $4^{\circ} \mathrm{C}$ overnight. After washing, secondary antibodies supplied by GeneTex (Irvine, CA, USA) were used at a 1:10,000 dilution for horseradish peroxidase (HRP)conjugated goat anti-rabbit IgG (GTX213110), HRP-conjugated donkey anti-goat IgG (GTX26885) and HRP-conjugated rabbit antimouse $\operatorname{IgG}(\mathrm{GTX} 213112)$ for $1 \mathrm{~h}$ at room temperature $\left(25^{\circ} \mathrm{C}\right)$. Subsequently, proteins were visualized via chemiluminescence signals enhanced using electrochemiluminescence detection
(Amersham ECL ${ }^{\mathrm{TM}}$; GE Healthcare, Chicago, IL, USA). ImageJ version $1.49 \mathrm{o}$ software (National Institutes of Health, Bethesda, MD, USA) was used to quantify changes in protein expression by densitometric analysis using $\beta$-actin as the loading control (37).

Confocal laser scanning microscopy assay. HSC3 cells $\left(5 \times 10^{4}\right.$ cells $/ \mathrm{ml}$ ) were kept on 12 -well chamber slides and were treated with fisetin $(0$ and $40 \mu \mathrm{M})$ for 24 hours, then fixed with $4 \%$ formaldehyde in PBS for $15 \mathrm{~min}$. Cells were incubated $0.3 \%$ Triton$\times 100$ in PBS for $1 \mathrm{~h}$ to permeable the cells for blocking non-specific binding sites by using $2 \%$ bovine serum albumin. Cells were stained by primary antibodies to cytochrome $c$, AIF and ENDO G (all in green fluorescence) overnight followed by secondary antibody [fluorescein isothyocyanate-conjugated goat anti-mouse (or rabbit or goat) $\mathrm{IgG}$ ] and PI (red fluorescence) staining for examination of nuclei. Slides were mounted, examined and photo-micrographed under a Leica TCS SP2 Confocal Spectral Microscope (Leica Microsystems, Bannockburn, IL, USA) (38).

Statistical analysis. All values are presented as the mean \pm standard deviation of three independent experiments. Differences between groups were analyzed by one-way analysis of variance and Dunnett test for multiple comparisons (SigmaPlot for Windows version 12.0; Systat Software, Inc., San Jose, CA). A value of $p<0.05$ was considered to indicate a statistically significant difference.

\section{Results}

Fisetin reduced the total cell viability of HSC3 cells. The cytotoxic effects were examined in HSC3 cells after exposure to different concentrations of fisetin for 24 and 48 hours. The results showed that fisetin reduces HSC 3 cell viability dose- and time-dependently (Figure 1).

Fisetin induced chromatin condensation (apoptotic cell death) in HSC3 cells. After HSC3 cells were exposed to fisetin $(40 \mu \mathrm{M})$ for $0,12,24$ and $48 \mathrm{~h}$, they were stained with DAPI and photographed by using fluorescence 


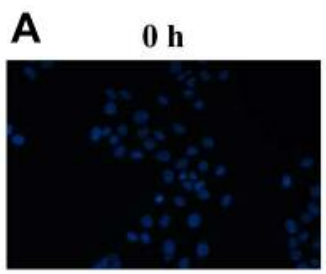

$24 \mathrm{~h}$

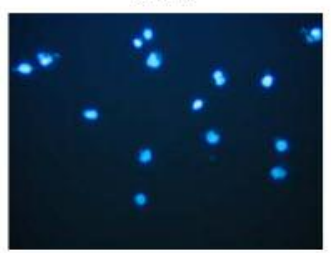

$12 \mathrm{~h}$

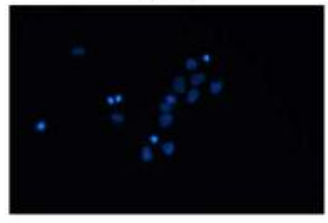

$48 \mathrm{~h}$

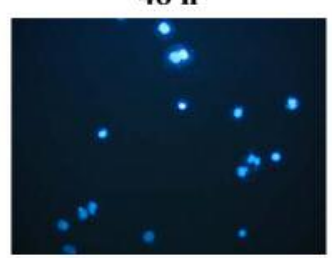

B

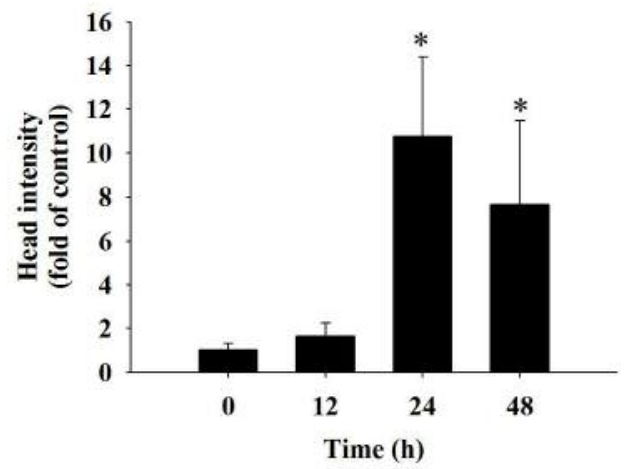

Figure 2. Fisetin induced chromatin condensation in HSC3 cells. Cells were treated with $40 \mu \mathrm{M}$ of fisetin for 0, 12, 24 and $48 \mathrm{~h}$ then were stained with 4' 6-diamidino-2-phenylindole (DAPI) (A) and total head intensity (fold of control) was evaluated (B) as described in the Materials and Methods section. *Significant differences at $p<0.05$ fisetin-treated groups and the control as analyzed by Dunnett test.

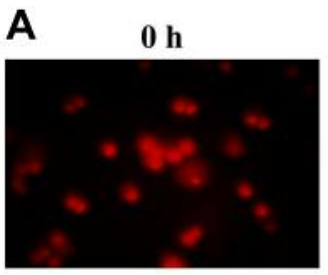

$24 \mathrm{~h}$

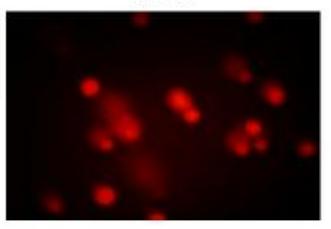

$12 \mathrm{~h}$

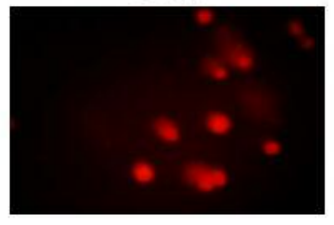

$48 \mathrm{~h}$

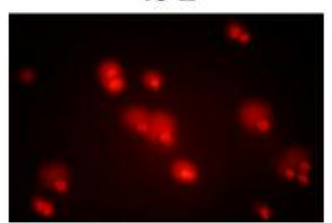

B

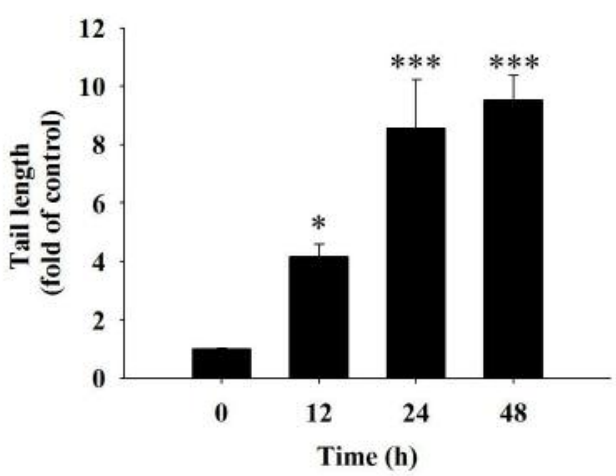

Figure 3. Fisetin induced DNA damage in HSC3 cells. Cells were treated with $40 \mu \mathrm{M}$ of fisetin for 0, 12, 24 and $48 \mathrm{~h}$ then the cells were measured by comet assay (A) for comet tail length $(B)$ as described in the Materials and Methods section. Significant differences at *p<0.05, and ***p<0.001 between fisetin-treated groups and the control as analyzed by Dunnett test.

microscopy. The results showed brighter fluorescence of HSC 3 cells after 24 and 48 h of treatment with $40 \mu \mathrm{M}$ fisetin (Figure 2A); the bright fluorescence represents nicked DNA and chromatin condensation. These effects also occurred in a time-dependent manner (Figure 2B).

Fisetin induced DNA damage in HSC3 cells. The comet assay measures DNA damage in cells after exposure to chemicals. HSC 3 cells were incubated with $40 \mu \mathrm{M}$ fisetin for $0,12,24$ and $48 \mathrm{~h}$ and were examined by comet assay. The results showed that fisetin induced a typical comet tail (DNA damage) (Figure 3A) and these effects were time-dependent
(Figure 3B). These results suggest that fisetin induces DNA damage in HSC3 cells.

Fisetin induced $\mathrm{ROS}$ production and $\mathrm{Ca}^{2+}$ release, and reduced the mitochondrial membrane potential $\left(\Psi_{m}\right)$ in HSC 3 cells. In order to further understand whether fisetin induces cell apoptosis in HSC3 cells through the production of ROS and $\mathrm{Ca}^{2+}$ or dysfunction of mitochondria, cells were treated with $40 \mu \mathrm{M}$ fisetin for different time periods and cells were collected and analyzed by flow cytometric assay. The results show that after 6-48 hours of treatment, fisetin increased ROS production (Figure 4A) and $\mathrm{Ca}^{2+}$ release 

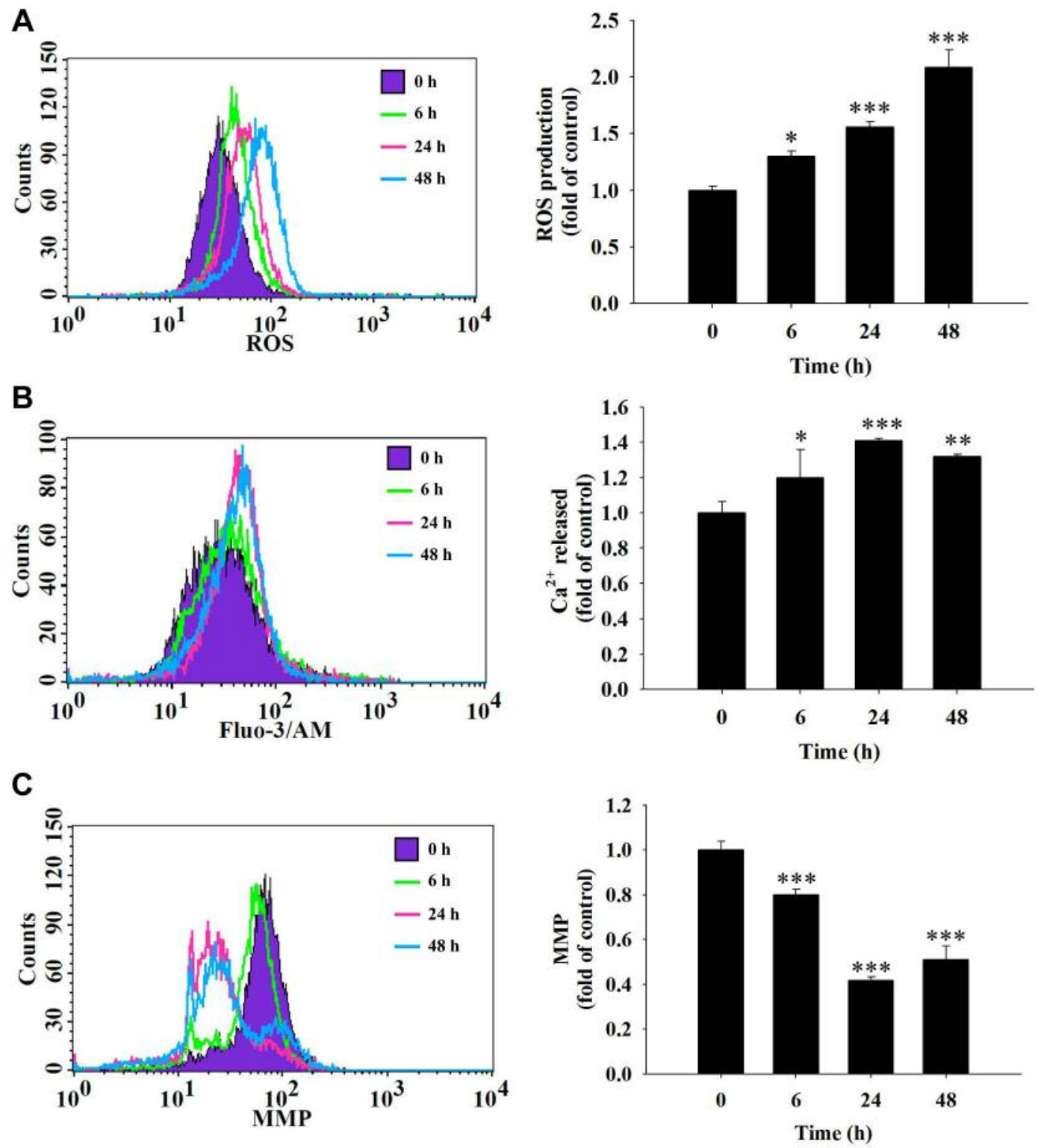

Figure 4. Fisetin induced reactive oxygen species (ROS) and $\mathrm{Ca}^{2+}$ production and reduced the mitochondrial membrane potential (MMP) in HSC 3 cells. Cells $\left(5 \times 10^{4}\right.$ cells $\left./ \mathrm{ml}\right)$ were treated with fisetin $(40 \mu \mathrm{M})$ for different time periods. Cells were isolated and then were re-suspended in $500 \mu \mathrm{l}$ of 2',7'-dichlorfluorescein-diacetate $(10 \mu \mathrm{M})$ for $30 \mathrm{~min}$ for determination of ROS (A), re-suspended in $500 \mu \mathrm{l}$ of fluo-3 acetomethoxyester $(2.5 \mu \mathrm{g} / \mathrm{ml})$ for 30 min for determination of intracellular $\mathrm{Ca}^{2+}$ concentration (B), and re-suspended in $500 \mu \mathrm{l}$ of 3,3'-dihexyloxacarbocyanine iodide (4 $4 \mathrm{~mol} / \mathrm{l})$ for $30 \mathrm{~min}$ for determination of $M M P(C)$ as described in the Materials and Methods section. Significant differences at $* p<0.05$, ** $p<0.01$, and $* * * p<0.001$ between fisetin-treated groups and the control as analyzed by Dunnett test.

(Figure 4B) but reduced $\Psi_{\mathrm{m}}$ (Figure $4 \mathrm{C}$ ). These results indicate that ROS, $\mathrm{Ca}^{2+}$ and $\Delta \Psi_{\mathrm{m}}$ are involved in fisetininduced cell apoptosis of HSC3 cells in vitro.

Fisetin increased the activities of caspase- $3,-8$ and -9 in HSC 3 cells. In order to further understand whether fisetin induces apoptotic cell death in HSC3 cells through the activation of caspases, cells were treated with $40 \mu \mathrm{M}$ fisetin for different time periods and cells were collected and analyzed by flow cytometric assay. The results show that fisetin increased caspase- 8 activation at $24 \mathrm{~h}$ of treatment (Figure 5A), increased caspase-9 (Figure 5B), and caspase- 3 activation (Figure 5C) from 6-48 h of treatment. These results indicate that caspase- $3,-8$ and -9 are involved in fisetin-induced cell apoptosis of $\mathrm{HSC} 3$ cells in vitro. 

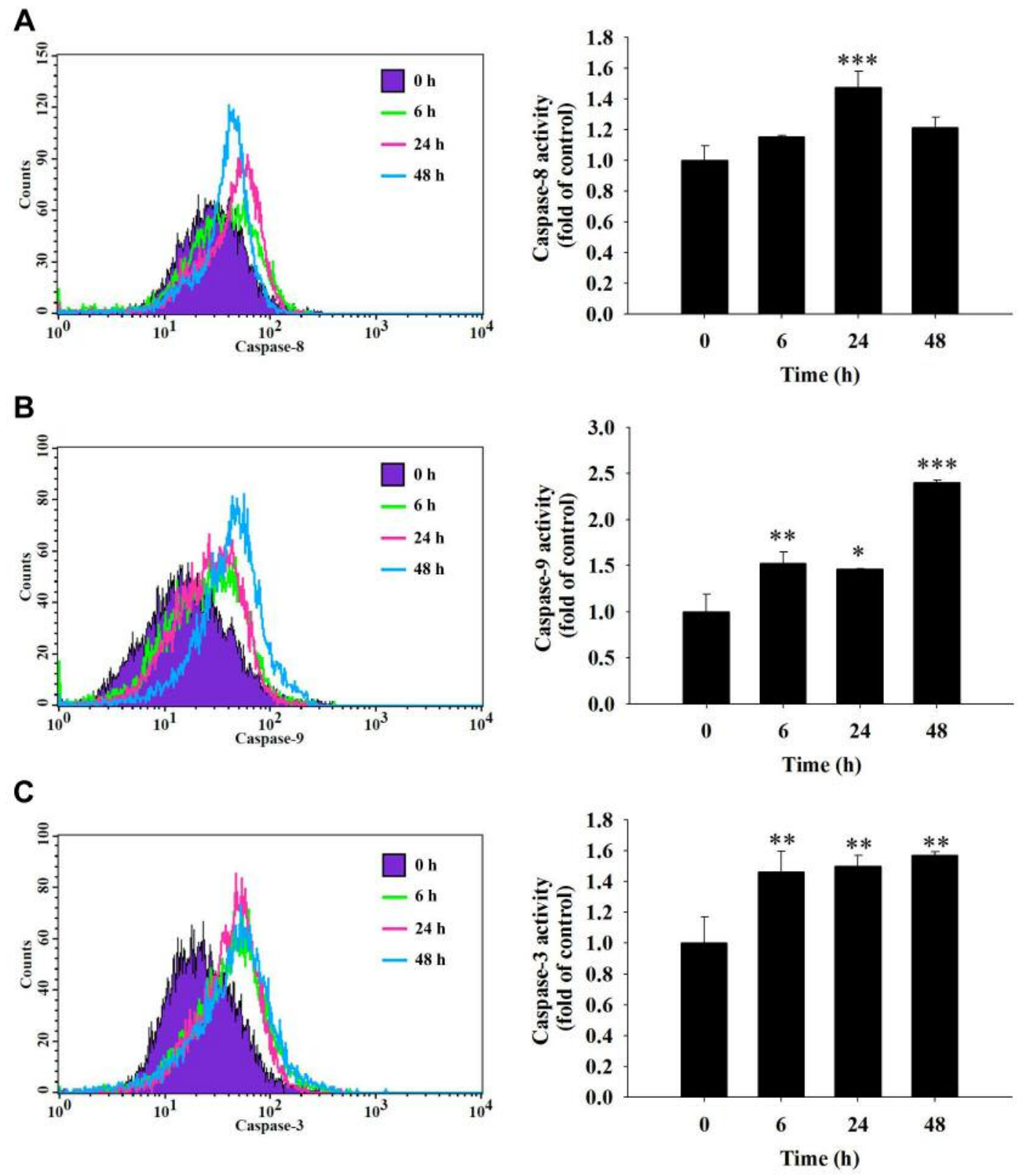

Figure 5. Fisetin induced the activity of caspase-3, caspase-8 and caspase-9 in HSC 3 cells. HSC 3 cells $\left(5 \times 10^{4}\right.$ cells/ml) were plated in a $12-$ well plate and treated with $40 \mu \mathrm{M}$ fisetin for 0, 6, 24 and $48 \mathrm{~h}$ then cells were harvested and re-suspended in $25 \mu \mathrm{l}$ of $10 \mu \mathrm{M}$ substrate solution containing CaspaLux8- $L_{l} D_{2}$ for caspase-8 (A), CaspaLux $9-M_{1} D_{2}$ for caspase-9 (B) or PhiPhiLux- $G_{l} D_{l}$ for caspase-3 activity determinations $(C)$ before being incubated at $37^{\circ} \mathrm{C}$ for $60 \mathrm{~min}$. After incubation, all samples were washed with PBS and caspase activities were analyzed by flow cytometry as described previously. Significant differences at $* p<0.05$, ** $p<0.01$, and $* * * p<0.001$ between fisetin-treated groups and the control as analyzed by Dunnett test.

Fisetin altered expression of apoptosis-associated proteins in HSC3 cells. HSC3 cells were treated with $40 \mu \mathrm{M}$ fisetin for different time periods and then apoptosis-associated proteins were examined and quantified with western blotting. The results show that fisetin significantly increased the expression of BID, BAD, BAK, BAX (Figure 6A), AIF,
ENDO G, cytochrome c, APAF1, cleaved form of caspase-9 (Figure 6B), cleaved form of caspase-3, caspase-6 and PARP (Figure 6C), FAS, FAS-ligand and cleaved form of caspase8 (Figure 6D), cleaved form of ATF-6 $\beta$, calpain 1, caspase4 and GRP78 (Figure 6E), but reduced the expression of MCL1, BCL2, BCL-x (Figure 6A), and XIAP (Figure 6C). 
These results indicate that fisetin induces apoptotic cell death of HSC3 cells through endoplasmic reticulum (ER) stress and mitochondria-dependent pathways.

Fisetin altered the translocation of apoptotic-associated proteins in HSC3 cells. In order to further confirm fisetin effects, we studied the translocation of cytochrome c, AIF, and Endo G in HSC3 cells. Cells were treated with or without $40 \mu \mathrm{M}$ of fisetin for $24 \mathrm{~h}$, and were then stained by anti-cytochrome $c$, -AIF and -ENDO G and examined by confocal laser microscopic systems and results. The results showed that fisetin increased cytochrome c (Figure 7A), AIF (Figure 7B) and ENDO G (Figure 7C) release from mitochondria into the cytoplasm when compared to the control group.

\section{Discussion}

It is well known that many flavonoids have antitumor or growth-suppressive capacity against various human tumor cell lines and fisetin is a flavonoid. Numerous reports have shown that fisetin induced cytotoxic effects on many human cancer cell lines through cell-cycle arrest and apoptosis (20, 22-29), however, there is no report demonstrating that fisetin induces apoptosis of human oral cancer cells, therefore, we investigated the cytotoxic effects of fisetin on HSC3 human oral cancer cells in vitro. It is well documented that the best strategy for anticancer drugs is to induce cancer cell apoptosis. The induction of apoptosis in cancer cells by fisetin may be one of its critical characteristics as a chemopreventive agent. Herein, we found that fisetin i) reduced the percentage of viable cells (Figure 1); ii) induced chromatin condensation (Figure 2) and DNA damage (apoptotic cell death) (Figure 3); iii) increased ROS and $\mathrm{Ca}^{2+}$ levels and reduced $\Psi_{\mathrm{m}}$ (Figure 4); iv) increased the activities of caspase-3, -8 and -9 (Figure 5); v) increased expression of pro-apoptotic proteins BAX, BAD and BAK, AIF, ENDO G and cytochrome $c$, cleaved caspases and reduced anti-apoptotic proteins BCL2 and BCL-X and XIAP (Figure 6); vi) induced release of cytochrome c, AIF and ENDO G from mitochondria into the cytoplasm (Figure 7).

It is well known that apoptotic cell death play a role in maintaining tissue homeostasis and eliminating unnecessary cells. Furthermore, the dysregulation of apoptosis is pivotal to tumorigenesis and cancer development. We used several methods, including DAPI and comet staining, to show that fisetin induced apoptosis of HSC3 cells. DAPI staining in cancer cells has been used as a method to measure apoptotic cell death $(39,40)$. We found that fisetin increased the productions of ROS and $\mathrm{Ca}^{2+}$ in HSC 3 cells (Figure 4A and B). It was reported that chemotherapeutic agents induced necrotic or apoptotic cell death in cancer cells via the generation of ROS (41). But another report showed that fisetin treatment of A375.S2 melanoma cells resulted in a significant decrease in ROS level (28), while another reported that fisetin stimulated generation of ROS in U266 multiple myeloma cells and induced apoptosis through activation of AMP-activated protein kinase pathways in a ROS-dependent manner (42). Thus, based on these observations, fisetininduced modulation of ROS may be cell type-dependent. It was reported that any stress negatively impacts upon the intracellular calcium level, which can trigger ER stress (43); ER stress sensor protein GRP78 can be useful therapeutic target to enhance tumor cell death (43). Numerous evidence has shown that anticancer drugs induce cell apoptosis through dysfunction of mitochondria or reduction of $\Psi_{m}$ (43-45). The results from our flow cytometric assay showed that fisetin reduced $\Psi_{\mathrm{m}}$ in HSC3 cells (Figure 4C). ROS and mitochondria play an important role in the stimulation of apoptosis, through a mechanism known as the intrinsic signaling pathway $(46,47)$. It was reported that fisetin plays a key role in the loss of $\Psi_{\mathrm{m}}$ leading to apoptosis and inhibiting tumor growth (48). The accumulation of excessive ROS leads to nuclear DNA damage, followed by disruption of the $\Psi \mathrm{m}$ and release of cytochrome $c$ into the cytosol, ultimately leading to apoptosis (47). Thus, we suggest that fisetin induces apoptosis of HSC3 cells via a mitochondriadependent pathway.

Caspases, cysteinyl aspartate-specific proteases, are involved in anticancer drug-induced cancer cell apoptosis, and can be activated during apoptosis in a self-amplifying cascade $(49,50)$. Our results revealed that fisetin significantly increased caspase-3, -8 and -9 expression (Figure 5), showing the involve $\neg$ ment of caspases in apoptosis of HSC3 cells. In HeLa human cervical ade $\neg$ nocarcinoma cells, it was reported that fisetin exposure led to both caspase- 8 and caspase- 3 activation (27). It is well documented that activations of both caspase- 8 and caspase9 trigger both the extrinsic and intrinsic cell apoptotic pathways (51-53). Our findings were confirmed by western blot analysis, showing the expression of cleaved caspase-3, -8 and -9 (Figure 6B-D) proteins were significantly increased. Activation of caspase- 8 is closely related with apoptosis signaling through the extrinsic pathway (54) and activated caspase- 8 links to the mitochondrial pathway through cleavage of the BCL2 family members from BID to the truncated p15 BID (tBID) (55). Overall, our findings indicate that activation of the intrinsic apoptotic pathway in HSC 3 cells after exposed to fisetin as a result of unresolved ER stress (GRP78 and cleaved form of ATF-6 $\beta$; Figure 6E) occurs through members of the BCL2 family which control the release of cytochrome $\mathrm{c}$ from the mitochondria.

It was reported that BCL 2 family proteins are implicated in the regulation of mitochondrial permeability transition pore opening and release of cytochrome $\mathrm{c}$ from mitochondria into the cytosol (56) followed by activation of caspase- 3 and 
A

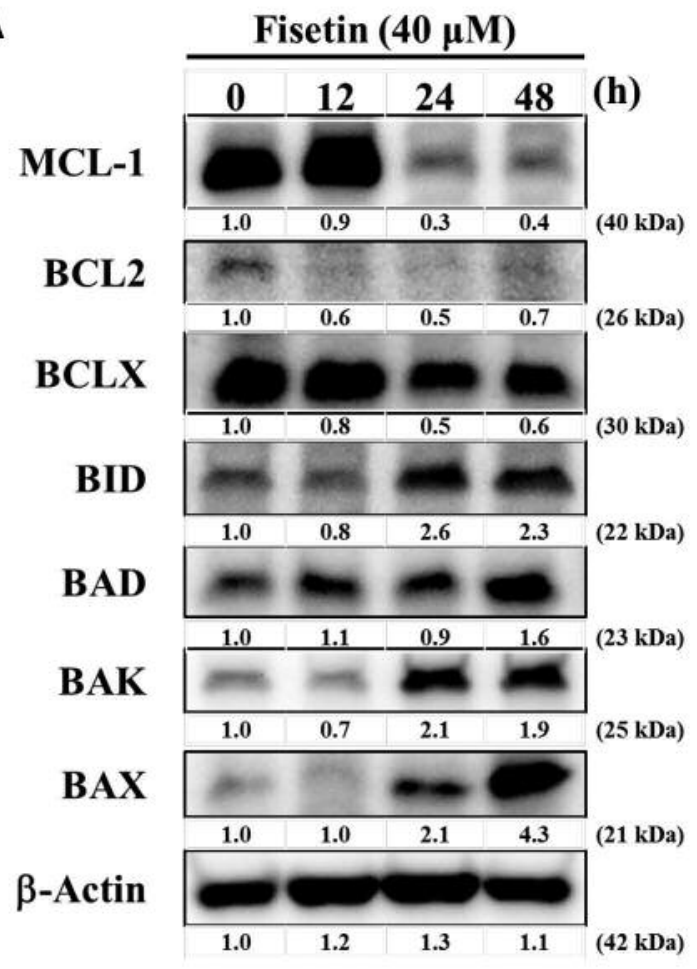

C

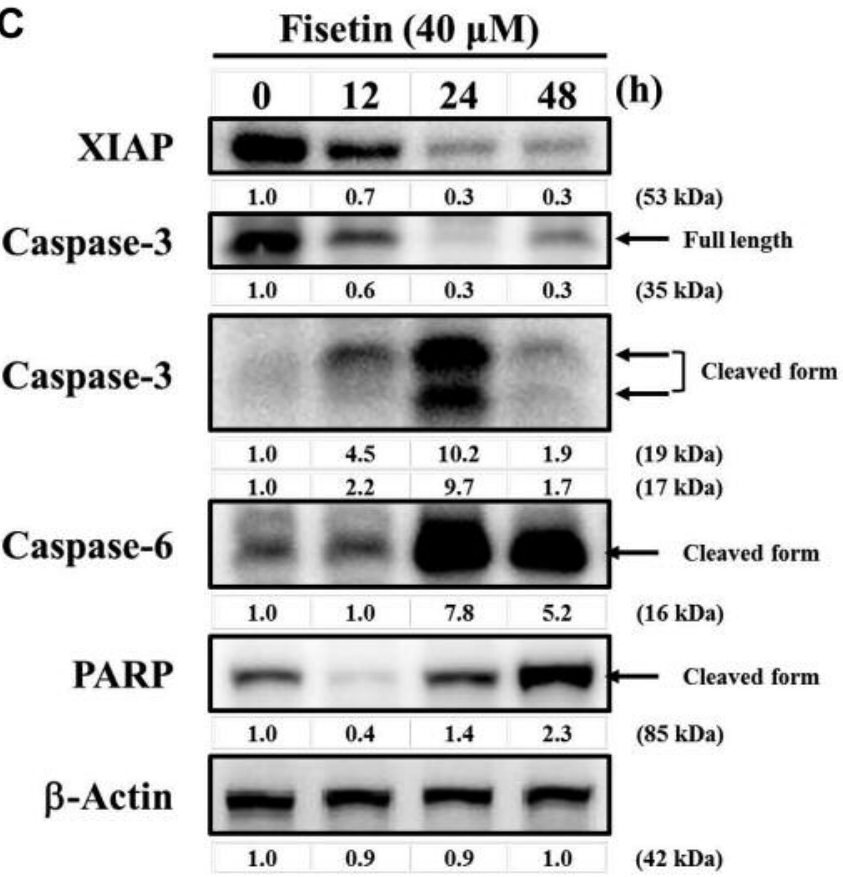

B
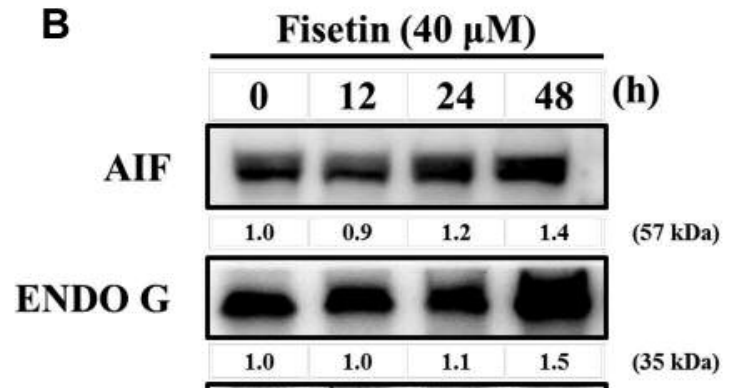

Cyto $c$

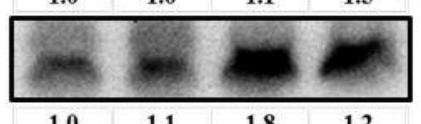

APAF1

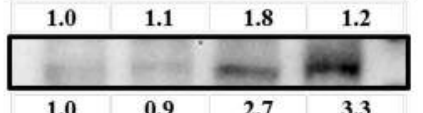

(15 kDa)

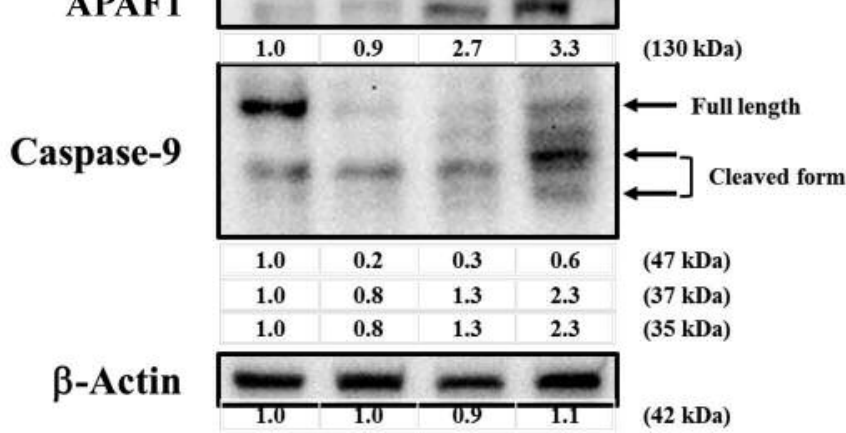

D

Fisetin $(40 \mu \mathrm{M})$

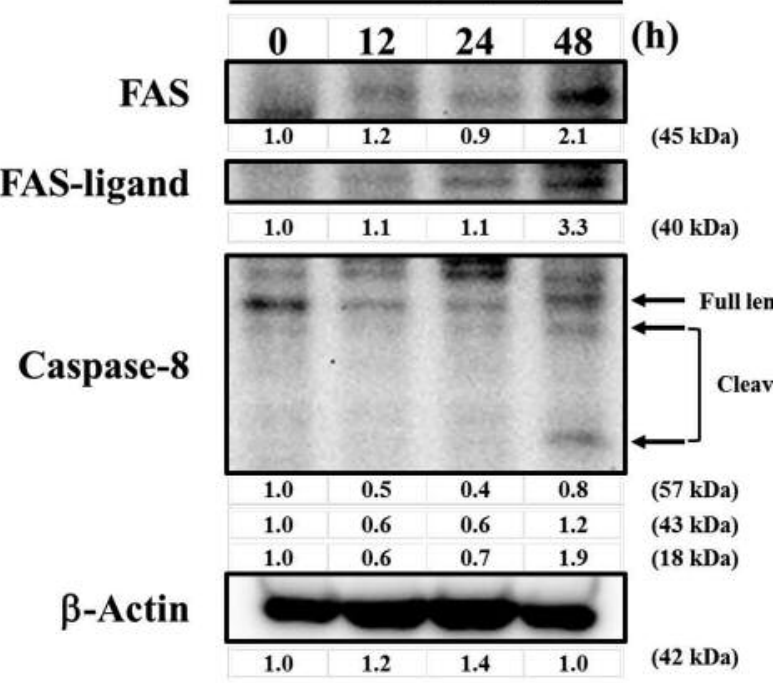

Figure 6. Continued

apoptosis (57-59). Our results indicated that fisetin upregulated the expression of BAX, BAD and BAK (Figure $6 \mathrm{~A})$, which are pro-apoptotic proteins, and caused downregulation of BCL2 and BCL-xL, which are anti-apoptotic proteins (Figure 6A). Therefore, alterations of BAX/BCL2 lead to dysfunction of mitochondria causing them to release cytochrome c (Figure 6B), and increased the active form of caspase-3 protein that led to apoptosis in HSC3 cells. 


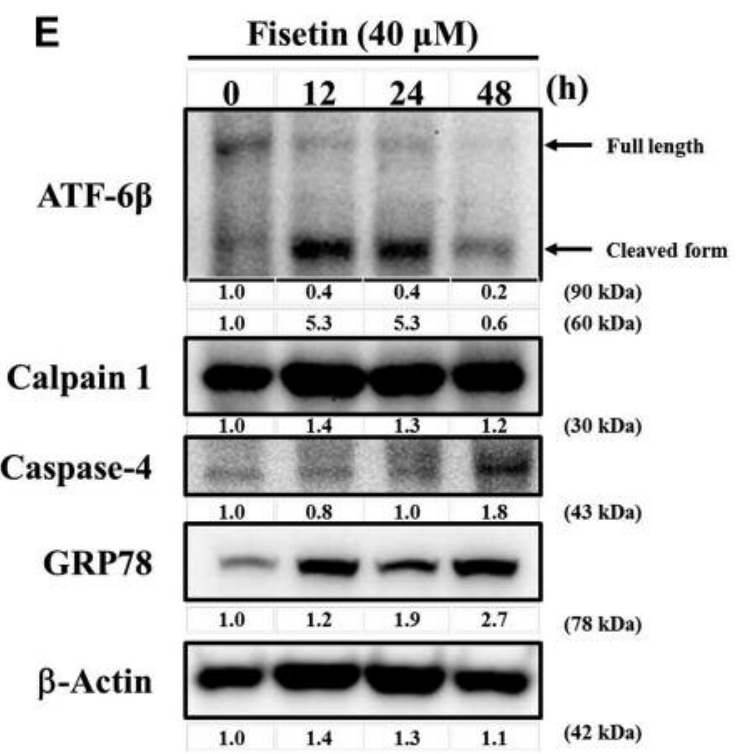

Figure 6. Fisetin affects expression of apoptosis-associated proteins in HSC 3 cells. Cells were treated with $40 \mu M$ fisetin for 0, 12, 24 and $48 \mathrm{~h}$ and then total proteins were quantitated and apoptosis associated proteins were measured by western blotting as described in the Materials and Methods section. A: Myeloid cell leukemia-1 (MCL1), B-cell lymphoma 2 (BCL2), apoptosis regulator BCL-X (BCLX), BH3-interacting domain death agonist (BID), BCL2-associated agonist of cell death (BAD), BCL2 antagonist/killer (BAK), BCL2-associated X $(B A X)$. B: Apoptosis-inducing factor $(A I F)$, endonuclease $G(E N D O G)$, cytochrome $c$, apoptotic peptidase-activating factor 1 (APAF1), caspase-9. C: X-linked inhibitor of apoptosis (XIAP), caspase-3, caspase-6 and poly-(ADP-ribose) polymerase (PARP). D: Fas cell surface death receptor (FAS), FAS-ligand and caspase-8. E: Activating transcription factor 6-beta (ATF-6 $\beta$ ), calpain 1, caspase-4 and glucose-regulated protein 78 (GRP78).

Moreover, our data show that fisetin up-regulated GRP78 and cleaved form of ATF- $6 \beta$ that induced ER stress in HSC3 cells (Figure 6E).

Our results shown in Figure 6B indicated that fisetin increased the expression of cytochrome c, AIF and ENDO G in HSC 3 cells, and by confocal laser microscopy examination we also found that fisetin promoted the release of cytochrome c, AIF and ENDO G in HSC3 cells from mitochondria into the cytoplasm (Figure 7-C). Based on these observations, we suggesting fisetin-induced apoptotic cell death may also occur through mitochondria-dependent pathway in HSC3 cells.

In conclusion, we examined the cytotoxic effects of fisetin on human oral cancer HSC3 cells in vitro and found that fisetin reduced viable cells through the induction of apoptosis. Fisetin triggered apoptotic cell death via the induction of ROS, ER stress and by disrupting the mitochondria membrane potential, which caused cytochrome $c$, AIF and ENDO G release from mitochondria into the cytosol. Cytochrome $c$ subsequently activated caspase- 9 and

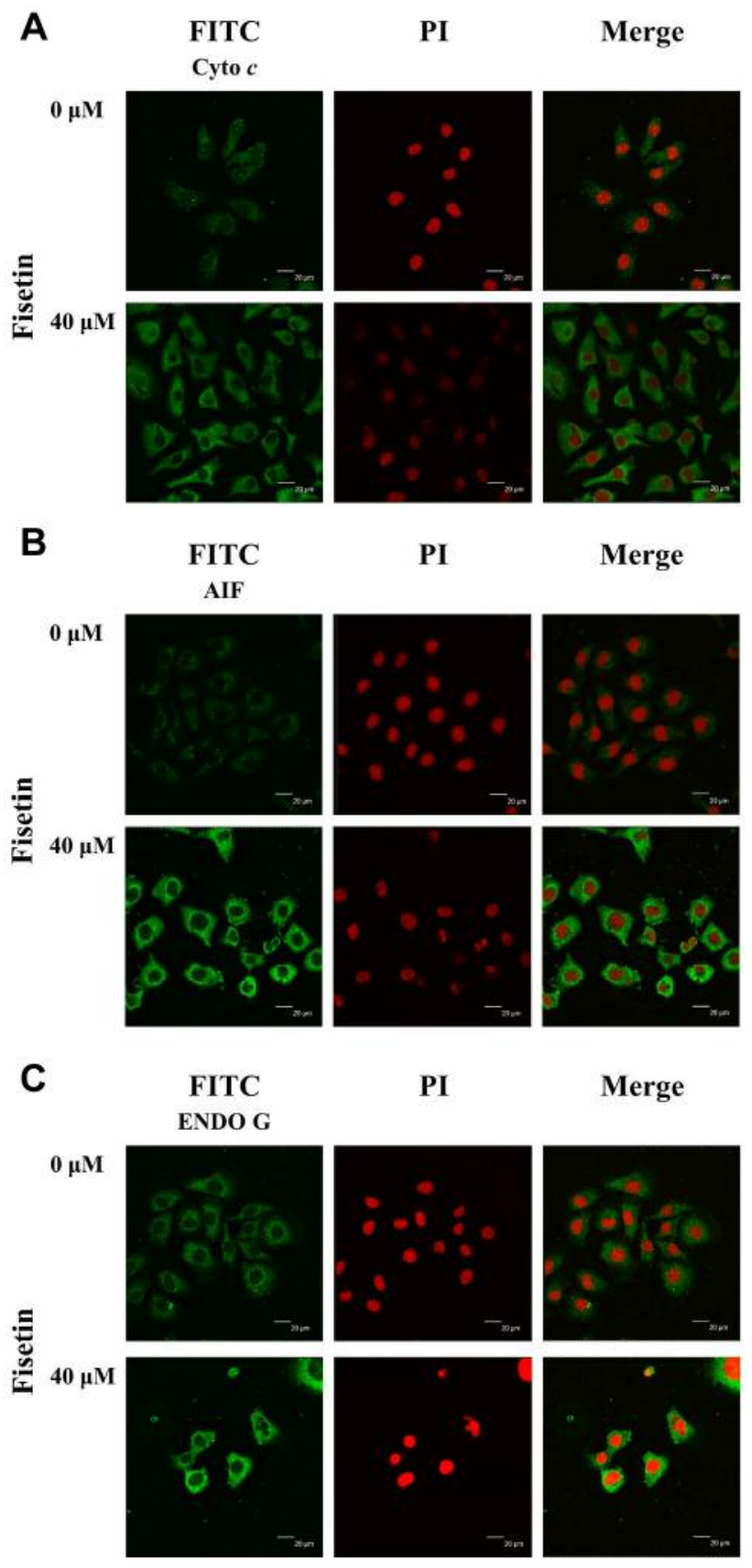

Figure 7. Fisetin affects the translocation of apoptotic-associated proteins in HSC 3 cells. Cells were treated with $40 \mu \mathrm{M}$ fisetin for $24 \mathrm{~h}$ and cells were stained by antitobodies to cytochrome $c(A)$, apoptosis-inducing factor $(A I F)(B)$ and endonuclease $G(E N D O G)(C)$ and then were stained with a secondary antibody and photographed by a Leica TCS SP2 confocal laser microscopic system as described in the Materials and Methods section.

downstream executioner caspase-3, leading to apoptosis. Apoptosis via the extrinsic pathway, which involves caspases (caspase-8), and the intrinsic pathways leading to AIF and 

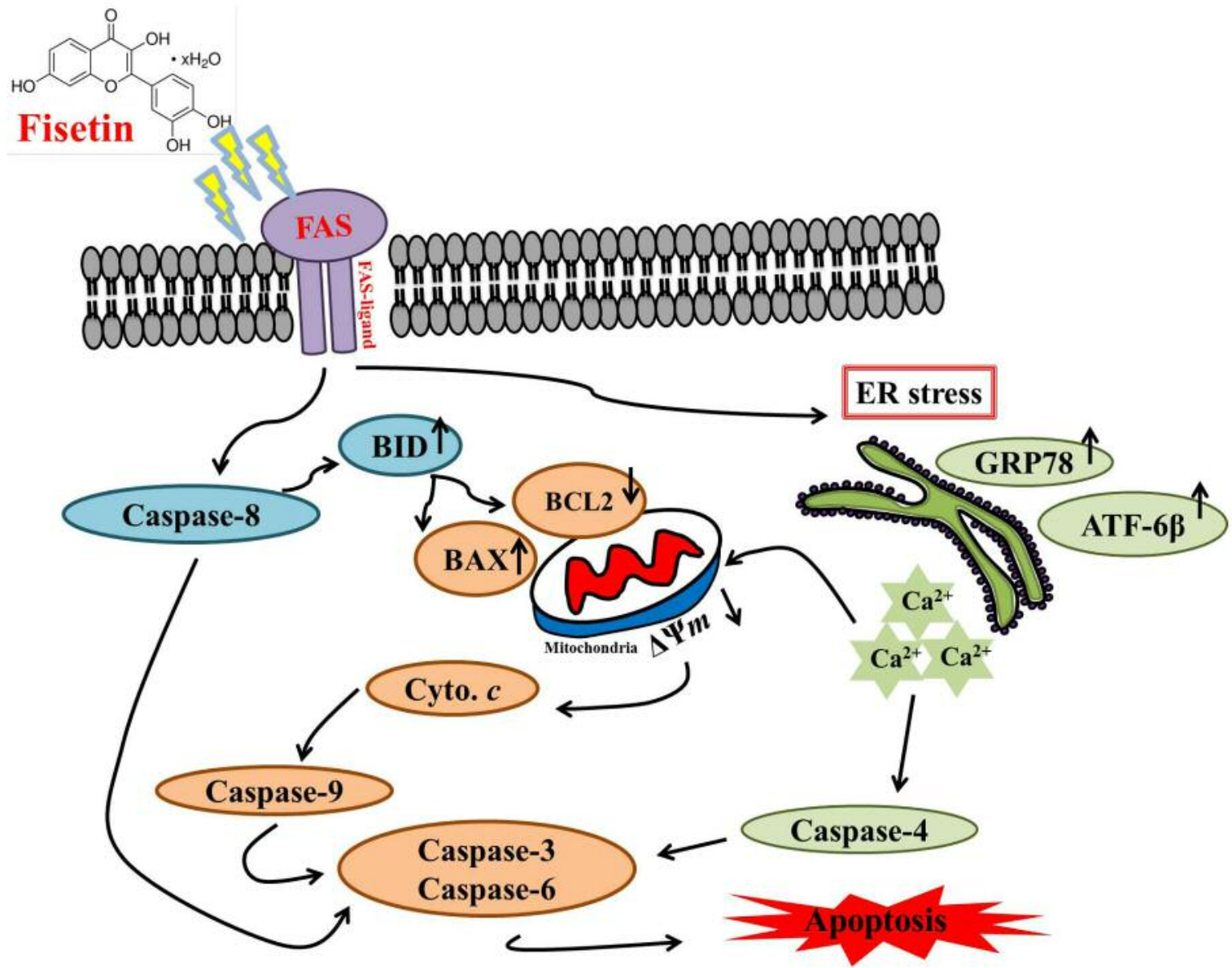

Figure 8. The possible signaling pathways for fisetin-induced apoptosis in HSC3 human oral cancer cells. B-cell lymphoma 2 (BCL2), BH3interacting domain death agonist (BID), BCL2-associated X (BAX). Apoptosis-inducing factor (AIF), endonuclease $G(E N D O G)$, cytochrome $c$

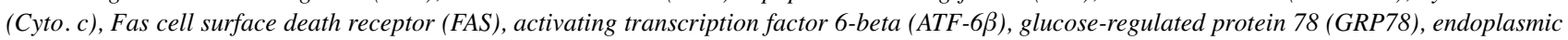
reticulum (ER) stress), calcium $\left(\mathrm{Ca}^{2+}\right)$, mitochondrial membrane potential $\left(\Psi_{m}\right)$.

ENDO G release from mitochondria causing apoptosis are summarized in Figure 8.

\section{Acknowledgements}

This study was supported by the grant 103-48 from Cheng Hsin General Hospital and by the grant SKH-8302-103-NDR-09 from Shin Kong Wu Ho-Su Memorial Hospital, Taipei, Taiwan. Experiments and data analysis were performed in part through the use of the Medical Research Core Facilities Center, Office of Research \& Development at China medical University, Taichung, Taiwan.

\section{References}

1 Cals FL, Bakker Schut TC, Hardillo JA, Baatenburg de Jong RJ, Koljenovic S and Puppels GJ: Investigation of the potential of Raman spectroscopy for oral cancer detection in surgical margins. Lab Invest 95: 1186-1196, 2015.
2 Khalili J: Oral cancer: risk factors, prevention and diagnostic. Exp Oncol 30: 259-264, 2008.

3 Ministry of Health and Welfare: 2016 Statistics of Causes of Death. 2017. Taiwan, ROC.

4 Major AG, Pitty LP and Farah CS: Cancer stem cell markers in head and neck squamous cell carcinoma. Stem Cells Int 2013: 319489, 2013.

5 Gomez DR, Zhung JE, Gomez J, Chan K, Wu AJ, Wolden SL, Pfister DG, Shaha A, Shah JP, Kraus DH, Wong RJ and Lee NY: Intensity-modulated radiotherapy in postoperative treatment of oral cavity cancers. Int J Radiat Oncol Biol Phys 73: 1096-1103, 2009.

6 Taylor WR and Stark GR: Regulation of the $\mathrm{G}_{2} / \mathrm{M}$ transition by p53. Oncogene 20: 1803-1815, 2001.

7 Lawen A: Apoptosis-an introduction. Bioessays 25: 888-896, 2003.

8 Liu B, Cheng Y, Bian HJ and Bao JK: Molecular mechanisms of Polygonatum cyrtonema lectin-induced apoptosis and autophagy in cancer cells. Autophagy 5: 253-255, 2009. 
9 Robertson JD and Orrenius S: Molecular mechanisms of apoptosis induced by cytotoxic chemicals. Crit Rev Toxicol 30: 609-627, 2000.

10 Wang CM, Xu SY, Lai S, Geng D, Huang JM and Huo XY: Curculigo orchioides (Xian Mao) modifies the activity and protein expression of CYP3A in normal and Kidney-Yang Deficiency model rats. J Ethnopharmacol 144: 33-38, 2012.

11 Beato VM, Orgaz F, Mansilla F and Montano A: Changes in phenolic compounds in garlic (Allium sativum L.) owing to the cultivar and location of growth. Plant Foods Hum Nutr 66: 218223, 2011.

12 Moustapha B, Marina GA, Raul FO, Raquel CM and Mahinda M: Chemical constituents of the Mexican mistletoe (Psittacanthus calyculatus). Molecules 16: 9397-9403, 2011.

13 Ren W, Qiao Z, Wang H, Zhu L and Zhang L: Flavonoids: promising anticancer agents. Med Res Rev 23: 519-534, 2003.

14 Arai Y, Watanabe S, Kimira M, Shimoi K, Mochizuki R and Kinae N: Dietary intakes of flavonols, flavones and isoflavones by Japanese women and the inverse correlation between quercetin intake and plasma LDL cholesterol concentration. $\mathrm{J}$ Nutr 130: 2243-2250, 2000.

15 Hanneken A, Lin FF, Johnson J and Maher P: Flavonoids protect human retinal pigment epithelial cells from oxidative-stressinduced death. Invest Ophthalmol Vis Sci 47: 3164-3177, 2006.

16 Higa S, Hirano T, Kotani M, Matsumoto M, Fujita A, Suemura M, Kawase I and Tanaka T: Fisetin, a flavonol, inhibits TH2type cytokine production by activated human basophils. J Allergy Clin Immunol 111: 1299-1306, 2003.

17 Chen CM, Hsieh YH, Hwang JM, Jan HJ, Hsieh SC, Lin SH and Lai CY: Fisetin suppresses ADAM9 expression and inhibits invasion of glioma cancer cells through increased phosphorylation of ERK1/2. Tumour Biol 36: 3407-3415, 2015.

18 Noh EM, Park YJ, Kim JM, Kim MS, Kim HR, Song HK, Hong OY, So HS, Yang SH, Kim JS, Park SH, Youn HJ, You YO, Choi $\mathrm{KB}$, Kwon KB and Lee YR: Fisetin regulates TPA-induced breast cell invasion by suppressing matrix metalloproteinase- 9 activation via the PKC/ROS/MAPK pathways. Eur J Pharmacol 764: 79-86, 2015.

19 Lee JD, Huh JE, Jeon G, Yang HR, Woo HS, Choi DY and Park DS: Flavonol-rich RVHxR from Rhus verniciflua Stokes and its major compound fisetin inhibits inflammation-related cytokines and angiogenic factor in rheumatoid arthritic fibroblast-like synovial cells and in vivo models. Int Immunopharmacol 9: 268276, 2009.

20 Sung B, Pandey MK and Aggarwal BB: Fisetin, an inhibitor of cyclin-dependent kinase 6 , down-regulates nuclear factorkappaB-regulated cell proliferation, antiapoptotic and metastatic gene products through the suppression of TAK-1 and receptorinteracting protein-regulated IkappaBalpha kinase activation. Mol Pharmacol 71: 1703-1714, 2007.

21 Chen YC, Shen SC, Lee WR, Lin HY, Ko CH, Shih CM and Yang LL: Wogonin and fisetin induction of apoptosis through activation of caspase 3 cascade and alternative expression of p21 protein in hepatocellular carcinoma cells SK-HEP-1. Arch Toxicol 76: 351-359, 2002.

22 Khan N, Afaq F, Syed DN and Mukhtar H: Fisetin, a novel dietary flavonoid, causes apoptosis and cell cycle arrest in human prostate cancer LNCaP cells. Carcinogenesis 29: 10491056, 2008.
23 Haddad AQ, Fleshner N, Nelson C, Saour B, Musquera M, Venkateswaran V and Klotz L: Antiproliferative mechanisms of the flavonoids 2,2'-dihydroxychalcone and fisetin in human prostate cancer cells. Nutr Cancer 62: 668-681, 2010.

24 Kang KA, Piao MJ and Hyun JW: Fisetin induces apoptosis in human nonsmall lung cancer cells via a mitochondria-mediated pathway. In Vitro Cell Dev Biol Anim 51: 300-309, 2015.

25 Murtaza I, Adhami VM, Hafeez BB, Saleem M and Mukhtar H: Fisetin, a natural flavonoid, targets chemoresistant human pancreatic cancer AsPC-1 cells through DR3-mediated inhibition of NF-kappaB. Int J Cancer 125: 2465-2473, 2009.

26 Suh Y, Afaq F, Khan N, Johnson JJ, Khusro FH and Mukhtar H: Fisetin induces autophagic cell death through suppression of mTOR signaling pathway in prostate cancer cells. Carcinogenesis 31: 1424-1433, 2010.

27 Ying TH, Yang SF, Tsai SJ, Hsieh SC, Huang YC, Bau DT and Hsieh YH: Fisetin induces apoptosis in human cervical cancer HeLa cells through ERK1/2-mediated activation of caspase-8/caspase-3-dependent pathway. Arch Toxicol 86: 263-273, 2012.

28 Syed DN, Lall RK, Chamcheu JC, Haidar O and Mukhtar H: Involvement of ER stress and activation of apoptotic pathways in fisetin induced cytotoxicity in human melanoma. Arch Biochem Biophys 563: 108-117, 2014.

29 Ash D, Subramanian M, Surolia A and Shaha C: Nitric oxide is the key mediator of death induced by fisetin in human acute monocytic leukemia cells. Am J Cancer Res 5: 481-497, 2015.

30 Yu FS, Yu CS, Chen JC, Yang JL, Lu HF, Chang SJ, Lin MW and Chung JG: Tetrandrine induces apoptosis Via caspase-8, -9, and 3 and poly (ADP ribose) polymerase dependent pathways and autophagy through beclin-1/LC3-I, II signaling pathways in human oral cancer HSC-3 cells. Environ Toxicol 31: 395-406, 2016.

31 Chu YL, Ho CT, Chung JG, Raghu R, Lo YC and Sheen LY: Allicin induces anti-human liver cancer cells through the $p 53$ gene modulating apoptosis and autophagy. J Agric Food Chem 61: 9839-9848, 2013.

32 Huang WW, Chiu YJ, Fan MJ, Lu HF, Yeh HF, Li KH, Chen PY, Chung JG and Yang JS: Kaempferol induced apoptosis via endoplasmic reticulum stress and mitochondria-dependent pathway in human osteosarcoma U-2 OS cells. Mol Nutr Food Res 54: 1585-1595, 2010.

33 Hsia TC, Yu CC, Hsu SC, Tang NY, Lu HF, Huang YP, Wu SH, Lin JG and Chung JG: Cantharidin induces apoptosis of H460 human lung cancer cells through mitochondria-dependent pathways. Int J Oncol 45: 245-254, 2014.

34 Liu KC, Yen CY, Wu RS, Yang JS, Lu HF, Lu KW, Lo C, Chen HY, Tang NY, Wu CC and Chung JG: The roles of endoplasmic reticulum stress and mitochondrial apoptotic signaling pathway in quercetin-mediated cell death of human prostate cancer PC-3 cells. Environ Toxicol 29: 428-439, 2014.

35 Lee MR, Lin C, Lu CC, Kuo SC, Tsao JW, Juan YN, Chiu HY, Lee FY, Yang JS and Tsai FJ: YC- 1 induces $\mathrm{G}_{0} / \mathrm{G}_{1}$ phase arrest and mitochondria-dependent apoptosis in cisplatin-resistant human oral cancer CAR cells. Biomedicine (Taipei) 7: 12, 2017.

36 Huang SH, Wu LW, Huang AC, Yu CC, Lien JC, Huang YP, Yang JS, Yang JH, Hsiao YP, Wood WG, Yu CS and Chung JG: Benzyl isothiocyanate (BITC) induces G2/M phase arrest and apoptosis in human melanoma A375.S2 cells through reactive oxygen species (ROS) and both mitochondria-dependent and death receptor-mediated multiple signaling pathways. J Agric Food Chem 60: 665-675, 2012. 
37 Huang YP and Chang NW: PPARalpha modulates gene expression profiles of mitochondrial energy metabolism in oral tumorigenesis. Biomedicine (Taipei) 6: 3, 2016.

38 Liu S-P, Hsu C-Y, Fu R-H, Huang Y-C, Chen S-Y, Lin S-Z and Shyu W-C: Sambucus williamsii induced embryonic stem cells differentiated into neurons. BioMedicine 5: 1-5, 2015.

39 Hsu YC, Chiang JH, Yu CS, Hsia TC, Wu RS, Lien JC, Lai KC, Yu FS and Chung JG: Antitumor effects of deguelin on H460 human lung cancer cells in vitro and in vivo: Roles of apoptotic cell death and H460 tumor xenografts model. Environ Toxicol 32: 84-98, 2017.

$40 \mathrm{Lu}$ CC, Yang JS, Chiang JH, Hour MJ, Lin KL, Lin JJ, Huang WW, Tsuzuki M, Lee TH and Chung JG: Novel quinazolinone MJ-29 triggers endoplasmic reticulum stress and intrinsic apoptosis in murine leukemia WEHI-3 cells and inhibits leukemic mice. PLoS One 7: e36831, 2012.

41 Trachootham D, Alexandre J and Huang P: Targeting cancer cells by ROS-mediated mechanisms: a radical therapeutic approach? Nat Rev Drug Discov 8: 579-591, 2009.

42 Liu WY and Jiang RS: Advances in the research of AMPK and its subunit genes. Pak J Biol Sci 16: 1459-1468, 2013.

43 Yang ST, Huang AC, Tang NY, Liu HC, Liao CL, Ji BC, Chou YC, Yang MD, Lu HF and Chung JG: Bisdemethoxycurcumininduced $\mathrm{S}$ phase arrest through the inhibition of cyclin $\mathrm{A}$ and $\mathrm{E}$ and induction of apoptosis via endoplasmic reticulum stress and mitochondria-dependent pathways in human lung cancer NCI H460 cells. Environ Toxicol 31: 1899-1908, 2016.

44 Huang AC, Chang CL, Yu CS, Chen PY, Yang JS, Ji BC, Lin TP, Chiu CF, Yeh SP, Huang YP, Lien JC and Chung JG: Induction of apoptosis by curcumin in murine myelomonocytic leukemia WEHI- 3 cells is mediated via endoplasmic reticulum stress and mitochondria-dependent pathways. Environ Toxicol 28: 255-266, 2013.

45 Ip SW, Chu YL, Yu CS, Chen PY, Ho HC, Yang JS, Huang HY, Chueh FS, Lai TY and Chung JG: Bee venom induces apoptosis through intracellular $\mathrm{Ca}^{2+}$-modulated intrinsic death pathway in human bladder cancer cells. Int J Urol 19: 61-70, 2012.

46 Mohan S, Abdelwahab SI, Kamalidehghan B, Syam S, May KS, Harmal NS, Shafifiyaz N, Hadi AH, Hashim NM, Rahmani M, Taha MM, Cheah SC and Zajmi A: Involvement of NF-kappaB and Bcl2/Bax signaling pathways in the apoptosis of MCF7 cells induced by a xanthone compound Pyranocycloartobiloxanthone A. Phytomedicine 19: 1007-1015, 2012.

47 Simon HU, Haj-Yehia A and Levi-Schaffer F: Role of reactive oxygen species (ROS) in apoptosis induction. Apoptosis 5: 415418,2000

48 Pal HC, Sharma S, Elmets CA, Athar M and Afaq F: Fisetin inhibits growth, induces $\mathrm{G}(2) / \mathrm{M}$ arrest and apoptosis of human epidermoid carcinoma A431 cells: role of mitochondrial membrane potential disruption and consequent caspases activation. Exp Dermatol 22: 470-475, 2013.
49 Chiu CH, Chou YC, Lin JP, Kuo CL, Lu HF, Huang YP, Yu CC, Lin ML and Chung JG: Chloroform extract of Solanum lyratum induced $\mathrm{G}_{0} / \mathrm{G}_{1}$ arrest via $\mathrm{p} 21 / \mathrm{p} 16$ and induced apoptosis via reactive oxygen species, caspases and mitochondrial pathways in human oral cancer cell lines. Am J Chin Med 43: 1453-1469, 2015.

50 Shang HS, Shih YL, Lee CH, Hsueh SC, Liu JY, Liao NC, Chen YL, Huang YP, Lu HF and Chung JG: Sulforaphane-induced apoptosis in human leukemia HL-60 cells through extrinsic and intrinsic signal pathways and altering associated genes expression assayed by cDNA microarray. Environ Toxicol 32: 311-328, 2017.

51 Grunnet LG, Aikin R, Tonnesen MF, Paraskevas S, Blaabjerg L, Storling J, Rosenberg L, Billestrup N, Maysinger D and Mandrup-Poulsen T: Proinflammatory cytokines activate the intrinsic apoptotic pathway in beta-cells. Diabetes 58: 18071815,2009

52 Moore F, Santin I, Nogueira TC, Gurzov EN, Marselli L, Marchetti P and Eizirik DL: The transcription factor C/EBP delta has anti-apoptotic and anti-inflammatory roles in pancreatic beta cells. PLoS One 7: e31062, 2012.

53 Santin I, Moore F, Colli ML, Gurzov EN, Marselli L, Marchetti P and Eizirik DL: PTPN2, a candidate gene for type 1 diabetes, modulates pancreatic beta-cell apoptosis via regulation of the BH3-only protein Bim. Diabetes 60: 3279-3288, 2011.

54 Jin Z, Li Y, Pitti R, Lawrence D, Pham VC, Lill JR and Ashkenazi A: Cullin3-based polyubiquitination and p62dependent aggregation of caspase- 8 mediate extrinsic apoptosis signaling. Cell 137: 721-735, 2009.

$55 \mathrm{Gu}$ Q, Wang JD, Xia HH, Lin MC, He H, Zou B, Tu SP, Yang Y, Liu XG, Lam SK, Wong WM, Chan AO, Yuen MF, Kung HF and Wong BC: Activation of the caspase-8/Bid and Bax pathways in aspirin-induced apoptosis in gastric cancer. Carcinogenesis 26: 541-546, 2005 .

56 Reed JC, Jurgensmeier JM and Matsuyama S: Bcl-2 family proteins and mitochondria. Biochim Biophys Acta 1366: 127137, 1998.

57 Bossy-Wetzel E and Green DR: Apoptosis: checkpoint at the mitochondrial frontier. Mutat Res 434: 243-251, 1999.

58 Herrera B, Alvarez AM, Sanchez A, Fernandez M, Roncero C, Benito $M$ and Fabregat I: Reactive oxygen species (ROS) mediates the mitochondrial-dependent apoptosis induced by transforming growth factor (beta) in fetal hepatocytes. FASEB J 15: 741-751, 2001

59 Raha S and Robinson BH: Mitochondria, oxygen free radicals, and apoptosis. Am J Med Genet 106: 62-70, 2001.

Received August 14, 2017

Revised September 8, 2017

Accepted September 14, 2017 